\title{
Economic evaluation of a crop rotation portfolio for irrigated farms in central Chile
}

\author{
Jorge González U. ${ }^{*}$, Pablo Undurraga ${ }^{1}$, Juan Hirzel${ }^{1}$, and Ingrid Martínez G. ${ }^{1}$
}

\begin{abstract}
The sustainable use of productive resources by agricultural producers in the central valley of Chile should be compatible with economic results so that producers can select an appropriate rotation or succession of annual crops and pasture. The objective of this work was to evaluate the economic behavior of four food crop and supplementary forage rotations using indicators of profitability and profit variability. Productive data were used from a long-term experiment (16 yr) in the central valley of Chile under conditions of irrigation. With productive data and information on historic input/output prices, the real net margin per rotation (RNMR) and its coefficient of variation (CV) were determined. The results indicated that the highest economic benefits and greatest economic stability were obtained with rotations that only included crops, namely sugar beet (Beta vulgaris L. subsp. vulgaris)-wheat (Triticum aestivum L.)-bean (Phaseolus vulgaris L.)-barley (Hordeum vulgare L.) (CR2) and corn (Zea mays L.)-wheat-bean-barley (CR4). These rotations included crops with low CV of the net margin, such as wheat, barley and beans, with values between 0.31 and 0.34 . The rotations with crops and pasture, sugar beet-wheat-red clover (Trifolium pratense L.) (2) (CR1) and corn-wheat-red clover (2) (CR3) had lower net margins and more variability of this indicator. Red clover had the highest CV value (1.00). The selection of crops for rotations and their sequence were determining factors in the economic behavior of rotations, affecting the level of RNMR and the degree of inter-annual variability of this indicator. Thus, differences among rotations of $47 \%$ in net margin were determined (CR2 vs. CR1), which only differed in the replacement of pasture with red clover (2) by bean-barley. The economic analysis based on the net margin and its variability allow for discriminating among rotations, providing valuable information for producers in deciding which crops to use in rotations.
\end{abstract}

Key words: Crop rotation, economic analyses, economic decision-making tools, portfolio of rotations, variation in net margin.

\section{INTRODUCTION}

Annual crops in Chile have undergone changes because of economic globalization; this has caused falling prices for domestic farmers in recent years because of increased corn, sugar, wheat, rice, and legume imports. Furthermore, the annual sowing area has decreased from 833022 ha in the 2002/2003 season to 689227 ha in the 2008/2009 season (ODEPA, 2009a). Important areas, such as the south central irrigated valley $\left(34^{\circ} 35^{\prime}\right.$ to $37^{\circ} 30^{\prime}$ S lat) (Del Pozo and Del Canto, 1999), have experienced significant changes; current rotations have not been productively and economically evaluated, although they maintain a socioeconomic role and good productive potential. Adequate crop rotation management helps to utilize their productive and economic potential. Zentner et al. (2002a) indicate that farmers who have diversified their crops increased their earnings in the medium term despite the higher production cost of some

${ }^{1}$ Instituto de Investigaciones Agropecuarias INIA, Av. Vicente Méndez 515, Chillán, Chile. *Corresponding author (jgonzale@inia.cl).

Received: 18 March 2013.

Accepted: 20 August 2013.

doi:10.4067/S0718-58392013000300006 crops in the rotation. The multipurpose role of a rotation, that is, environmental, productive, and economic factors (González and Ruz, 1994), involves decisions that affect agricultural systems and associated businesses. González et al. (2002a) postulate that economic performance of a rotation is crucial because appropriate crop selection affects economic benefits (Jatoe et al., 2008; Martin and Hanks, 2009). On the other hand, economic performance contributes to the continuity of a multipurpose rotation, but economic analysis studies of rotations are scarce (González et al., 2002b).

Crop profitability is subjected to management practices, product value, and productive resources. Crop planning in the rotation stabilizes profitability and variability (Saharawat et al., 2010). Rotations with harvested grasslands have transportation costs that affect profitability; therefore, the difference in expected returns between rotations should be carefully analyzed (Nielsen et al., 2011). Given its importance in the south central area, it should be noted that wheat usually generates benefits to the mean profitability of rotations. Studies of wheat-rice rotations by Guan et al. (2011) and dryland rotations in the Biobío Region, Chile, show this (González et al. 2002a). Selecting an appropriate crop rotation will produce more economically and productively sustainable agricultural 
systems by reducing the inadequate performance of some crops and expressing the potential of other crops included in the rotation (Nemecek et al., 2008).

Few studies have evaluated intensive and semiintensive rotations in a perspective of economic performance based on crop and sequence. The objective of this study was to carry out an economic evaluation of four crop and grassland rotations that represent production systems of the south central irrigated valley in Chile by using profitability and variability indicators.

\section{MATERIALS AND METHODS}

A major part of the irrigated valley of central-southern Chile $\left(34^{\circ} 35^{\prime}\right.$ to $37^{\circ} 30^{\prime} \mathrm{S}$ lat), which lies between the interior dryland to the West and Andean foothills to the East (Del Pozo and Del Canto, 1999), is devoted to agricultural and cattle production. The Agricultural Research Institute (Instituto de Investigaciones Agropecuarias INIA) carried out a study of rotations beginning in 1992 using the most important production systems in the area. The results are an important source of information for this economic study. The assay was conducted at the Quilamapu Regional Research Center (36 $31^{\prime}$ S , 71 ${ }^{\circ} 54^{\prime}$ W) of INIA in Chillán, Chile. The soil is classified as a Humic Haploxerands (Stolpe, 2006) originating from volcanic ash deposited over alluvial gravel.

The regional climate is Mediterranean, with a mean annual precipitation of $1150 \mathrm{~mm}$ (Undurraga et al., 2009). The rotation assay that began in 1992 included four intensive rotations, all 4-yr in length (Table 1). The experimental design was randomized complete blocks with four replicates on plots of $560 \mathrm{~m}^{2}(14 \times 40 \mathrm{~m})$. Cultivation was conduct at the real scale with conventional agricultural machinery to provide conditions similar to the agricultural systems they represented.

The CR1 rotation (sugar beet, Beta vulgaris L. subsp. vulgaris-wheat, Triticum aestivum L.-red clover, Trifolium pratense L.- red clover) began with sugar beet and ended with red clover for cutting; CR2 rotation (sugar beet-wheat-bean, Phaseolus vulgaris L.-barley, Hordeum vulgare L.) also began with sugar beet, but included only annual crops; CR3 rotation (corn, Zea mays L.-wheatred clover-red clover) began with silage corn and ended with red clover; the CR4 rotation (corn-wheat-beanbarley) began with grain corn and only included annual crops (Table 1). Wheat was present in all the rotations as the second crop in the sequence. Similar applications of

Table 1. Rotation system and details of crop sequence.

\begin{tabular}{|c|c|c|c|c|c|}
\hline $\begin{array}{l}\text { Rotation } \\
\text { system }\end{array}$ & $\begin{array}{l}\text { Farming } \\
\text { system }\end{array}$ & $\begin{array}{l}\text { First } \\
\text { year }\end{array}$ & $\begin{array}{l}\text { Second } \\
\text { year }\end{array}$ & $\begin{array}{l}\text { Third } \\
\text { year }\end{array}$ & $\begin{array}{c}\text { Fourth } \\
\text { year }\end{array}$ \\
\hline CR1 & Crop-livestock & Sugar beet & Wheat & Red clover & Red clover \\
\hline CR2 & Crop & Sugar beet & Wheat & Bean & Barley \\
\hline CR3 & Crop-livestock & Corn & Wheat & Red clover & Red clover \\
\hline CR4 & Crop & Silage corn & Wheat & Bean & Barley \\
\hline
\end{tabular}

inputs, labor and fertilizers were applied to all the crops and pastures independent of the rotation (Hirzel et al., 2011). Fertilization was adjusted seasonally based on recommendations from soil analysis (Hirzel, 2011) and using commercially available varieties.

\section{Determination, and valuing and systematization of economic data}

Agricultural information and annual output data for all the crops from the study of rotations were first organized and then systematized in technical-economic standards per crop/rotation to be submitted to economic analysis. Nominal annual prices for inputs, labor and production for each crop/year/rotation without the value added tax (VAT) going back to 1992 were gathered and organized, incorporating and systematizing all the annual information in the technical-economic standards. The prices incorporated at each standard were an annual average of the historic monthly, quarterly or semi-annual series drawn historical Chilean sources (Table 2).

Inputs (man hours, machine hours) and yields of each crop per season and their prices were included in the construction of each standard annual crop. The unit or scale of analysis was 1 ha.

The economical analysis was based on prices and nominal values expressed in Chilean pesos (CLP, Ch\$), but the final economical indicators, for comparison purpose were expressed in Chilean pesos $(\mathrm{Ch} \$)$ at the 2010 exchange rate. The final economic indicator values on tables and figures are expressed in US dollars (US\$) for 2011. Crop yields are expressed in $\mathrm{Mg} \mathrm{ha}^{-1}$ and pasture in $\mathrm{t} \mathrm{DM}_{\mathrm{ha}}{ }^{-1}$.

\section{Applied methodology of economic analysis}

The information gathered for all crops, seasons and rotations were gathered and analyzed economically in the theoretical framework of the mathematical model specified in Equation [1], in which the indicator of the economic benefit or final profitability is the real net margin per rotation (RNMR):

$$
\mathrm{RNMR}_{\mathrm{i}}=\mathrm{RGMR}_{\mathrm{i}}-\mathrm{CFRR}_{\mathrm{i}}
$$

where $\mathrm{i}=\mathrm{CR} 1, \mathrm{CR} 2 \ldots \mathrm{CR} 6$ rotation; $\mathrm{RNMR}_{\mathrm{i}}=$ real net margin per rotation " $\mathrm{i}$ "; $\mathrm{RGMR}_{\mathrm{i}}=$ real gross margin per rotation "i", and $\mathrm{CFRR}_{\mathrm{i}}=$ real fixed cost per rotation "i”. The RNMR was calculated for each 4-yr cycle for every rotation. A cycle is the agricultural development of the complete sequence of crops included in the rotation. The arithmetic average of each cycle is the final value considered in the analysis of the RNMR. The RNMR was

Table 2. Source of price data during the study period.

\begin{tabular}{lc}
\hline Sources of input/output price data & Base de datos \\
\hline Informativo Agropecuario Bioleche-INIA Quilamapu & $1999-2007$ \\
Banco Central de Chile & $1992-2010$ \\
Oficina de Estudios y Políticas Agrarias (ODEPA, 2009b) & $1992-2009$ \\
Boletín Económico y de Mercado, Sociedad Nacional de & $1991-1996$ \\
Agricultura (SNA, 1991-1996) & \\
\hline
\end{tabular}

INIA: Instituto de Investigaciones Agropecuarias. 
constructed according to the methodological specifications of Equations [2] to [6].

\section{Real gross margin per rotation (RGMR)}

The RGMR (Equation [2]) for each rotation is the average of the gross nominal margins, that is, with nominal prices, of crops included in each rotation the nominal gross margin per crop (NGMC), adjusted by a temporal correction factor (CF) based on the consumer price index (CPI). The CPI can present relatively high degree of month-to-month volatility, as a result of fluctuations in perishables and fuel prices. Therefore, to interpret periodic and short-term price information (up to 2-mo), the Central Bank also considers measures of underlying or trend inflation, such as variation in the underlying CPI maintained by the National Statistics Bureau (INE) of the Banco Central de Chile (2010):

$\mathrm{RGMR}_{\mathrm{i}}=\left(\mathrm{NGMC}_{\mathrm{a}} \times \mathrm{CF}_{\mathrm{a}}+\ldots \ldots \ldots \ldots+\mathrm{NGMC}_{\mathrm{n}} \times \mathrm{CF}_{\mathrm{n}}\right) \times$ $\mathrm{n}^{-1}$

where $\mathrm{NGMC}_{\mathrm{a}}=$ nominal gross margin per crop "a" of rotation "i"; $\mathrm{NGMC}_{\mathrm{n}}=$ nominal gross margin crop " $\mathrm{n}$ " of rotation "i"; $\mathrm{CF}_{\mathrm{a}}=$ correction factor CPI crop "a" in rotation " $\mathrm{i}$ "; $\mathrm{CF}_{\mathrm{n}}=$ correction factor CPI crop " $\mathrm{n}$ " in rotation " $\mathrm{i}$ ", and $\mathrm{n}^{-1}=$ inverse of " $\mathrm{n}$ " in NGMC of rotation "i". The expression NGMC $\times$ CF is termed the real gross margin per crop (RGMC) and is analyzed in the individual behavior of crops.

\section{Nominal gross margin per crop (NGMC)}

For a crop of a given rotation, the NGMC (Equation [3]) is obtained by subtracting the variable nominal cost (nominal prices) of the crop (NVCC) from the nominal gross income (NGIC) of that crop. Equation [3] specifies this relation for crop "a" in rotation "i":

$$
\mathrm{NGMC}_{\mathrm{a}}=\mathrm{NGIC}_{\mathrm{a}}-\mathrm{NVCC}_{\mathrm{a}}
$$

where NGIC $=$ nominal gross income per crop "a" in rotation "i", and NVCC $=$ nominal variable cost of crop "a" in rotation "i". The components of Equation 3], NGIC and NVCC are the two initial economic indicators generated in each technical-economic standard and are fundamental to finally economically value each rotation. It is calculated as described below:

Nominal gross income per crop (NGIC). The NGIC (Equation [4]) is determined by multiplying annual yield by the nominal annual average price of the related product:

$$
\mathrm{NGIC}_{\mathrm{a}}=\mathrm{R}_{\mathrm{a}} \times \mathrm{P}_{\mathrm{a}}
$$

where $R_{a}=$ yield of crop " $a$ " of rotation " $\mathrm{i}$ ", and $\mathrm{P}_{\mathrm{a}}=$ nominal annual price of producing crop "a" of rotation "i".

Nominal variable cost per crop (NVCC). Variable cost increases as the level of production increases. Thus, the NVCC for each crop/year/rotation is the sum of input $\left(\Sigma_{\mathrm{I}}\right)$ and labor costs $\left(\Sigma_{\mathrm{L}}\right)$, consigned in each technicaleconomic standard. The cost of inputs and/or labor is determined by multiplying the nominal annual price by the quantity of inputs or labor. Equation [5] specifies this relationship for crop "a" in rotation "i":

$\mathrm{NVCC}_{\mathrm{a}}=\Sigma_{\mathrm{I}}\left(\mathrm{PI}_{1} \times \mathrm{IQ}_{1}+\ldots . .+\mathrm{PI}_{\mathrm{n}} \times \mathrm{IQ}_{\mathrm{n}}\right)+\Sigma_{\mathrm{L}}\left(\mathrm{PL}_{1} \times \mathrm{LQ}_{1}\right.$ $\left.+\ldots . .+\mathrm{PL}_{\mathrm{n}} \times \mathrm{LQ}_{\mathrm{n}}\right)$

where $\mathrm{PI}_{1}=$ nominal annual input price " 1 " of crop "a"; $\mathrm{PI}_{\mathrm{n}}=$ nominal annual input price " $\mathrm{n}$ " of crop "a"; $\mathrm{IQ}_{1}=$ input quantity " 1 " of crop "a"; $\mathrm{IQ}_{\mathrm{n}}=$ input quantity "n" of crop "a"; $\mathrm{PL}_{1}=$ nominal annual labor price " 1 " of crop "a"; $\mathrm{PL}_{\mathrm{n}}=$ nominal annual labor price " $\mathrm{n}$ " of crop "a"; $\mathrm{LQ}_{1}=$ quantity of labor "1" of crop "a", and $\mathrm{LQ}_{\mathrm{n}}=$ quantity of labor " $n$ " of crop "a".

\section{Indicators for the economic analysis}

The economic indicators associated with generating wealth that were obtained to analyze the economic benefits of rotations are defined in Equations [1] and [2], that is, RNMR and RGMR, respectively. The standard deviation (SD) and coefficient of variation (CV) were calculated as indicators of dispersion or variability of economic benefits, according to the definitions and methodologies described by Edwards (1992).

\section{Correction of nominal margin to real margin and fixed costs}

The RGMR is calculated by adjusting NGMC with a CF or weight, with historic CPI data (official Chilean indicator that represents general rises in price levels). From this data a value is obtained for $\mathrm{CF}$ for each year, which allows for expressing nominal values for different years (NGMC) in terms of a currency of comparable value, the RGMC and upon calculating the average of RGMC of a rotation, is expressed as RGMR. Consequently, all NGMCs of each year are established in Chilean currency for December 2010, which is then changed to US currency values based on an exchange rate of US $\$ 1=\mathrm{Ch} \$ 500$. Thus, the weight or CF is defined by:

$$
\mathrm{CF}=\mathrm{CPI}_{2010} / \mathrm{CPI}_{\mathrm{j}}
$$

where $\mathrm{CPI}_{2010}=$ average consumer price index for 2010; $\mathrm{CPI}_{\mathrm{j}}=$ average CPI for year " $\mathrm{j}$ ", and “ $\mathrm{j}$ " = agricultural study years: 1992 to 2007. Fixed costs are costs that do not vary with the level of production at a given scale and over a given period of time. Fixed costs (Anderson et al., 1988) do not affect the profitability of a crop system directly. Its magnitude is more associated with a scale of operation or type of producer. Nevertheless, fixed costs are included because according to there magnitude does affect the true economic result of a productive activity give that they include the cost of using all the production resources. How much they affect a production system is determined by the difference between net RNMR and gross margins (RGMR) of Equation [1]. The assessment of fixed costs is based on the structure of fixed farm costs proposed by González et al. (2002b) for a farm type in the area under study with an average area of 85 ha, including the costs of accounting, taxes, administration, technical 
assistance, interest on loans, maintenance, depreciation of assets and general expenses, with their values adjusted by the respective $\mathrm{CF}$.

Crop yields and DM production of pastures, as determined for a $10 \mathrm{~m}^{2}$ area, were used to calculate incomes (Table 1). The results were analyzed by ANOVA $(\mathrm{P}<0.05)$. The Tukey means separation test was applied with the SAS software program version 9.1.3 Service Pack (SAS Institute, 2002-2003).

\section{RESULTS AND DISCUSSION}

\section{Crop yields and effect of rotation sequences}

The following analysis and discussion describes average yield of the crops included in each rotation. This information is also the basis to analyze the economic behavior, according to profitability and profit variability of each rotation.

The $16 \mathrm{yr}$ of the rotation study in 4-yr cycles in length resulted in differences in wheat yields associated with the rotations (Table 3). Yield was higher when wheat was preceded by sugar beet in CR1 (S-W-R-R) and CR2 (S-W-B-BR) (7.97 and $7.14 \mathrm{Mg} \mathrm{ha}^{-1}$, respectively) and lower when it was preceded by silage corn in CR3 (CSW-R-R) and grain corn in CR4 (C-W-B-BR) (6.29 and 6.47 $\mathrm{Mg} \mathrm{ha}^{-1}$, respectively).

Wheat yields obtained in the study were comparable to yields from previous studies in the area (Table 4), ranging between 6.9 and $8.9 \mathrm{Mg} \mathrm{ha}^{-1}$ (Mellado et al., 2000; Hirzel, 2011). Sugar beet yield was statistically the same in the

Table 3. Annual average yields of rotation crops and livestock. Average of $16 \mathrm{yr}$ of assessments.

\begin{tabular}{|c|c|c|c|c|}
\hline Crop & CR1 & $\mathrm{CR} 2$ & CR3 & CR4 \\
\hline & \multicolumn{4}{|c|}{$\mathrm{Mg} \mathrm{ha}^{-1}$} \\
\hline Wheat & $7.97 \pm 0.21 \mathrm{a}$ & $7.14 \pm 0.28 \mathrm{ab}$ & $6.29 \pm 0.19 \mathrm{c}$ & $6.47 \pm 0.17 \mathrm{bc}$ \\
\hline Sugar beet & $88.89 \pm 7.15 \mathrm{a}$ & $102.78 \pm 5.84 \mathrm{a}$ & & \\
\hline Bean & & $3.00 \pm 0.22 \mathrm{a}$ & & $3.05 \pm 0.25 \mathrm{a}$ \\
\hline Barley & & $6.48 \pm 0.26 \mathrm{a}$ & & $6.83 \pm 0.34 \mathrm{a}$ \\
\hline Corn & & & & $12.08 \pm 8.03$ \\
\hline \multirow[t]{2}{*}{ Pasture } & \multicolumn{4}{|c|}{ Yield } \\
\hline & \multicolumn{4}{|c|}{$\mathrm{DM} \mathrm{ha}^{-1}$} \\
\hline Red clover & $13.08 \pm 0.96 \mathrm{a}$ & \multicolumn{3}{|c|}{$12.00 \pm 0.92 \mathrm{a}$} \\
\hline Silage corn & & \multicolumn{3}{|c|}{$20.29 \pm 0.83 b$} \\
\hline
\end{tabular}

Different letters in the same row indicate significant differences according to Tukey test $(\mathrm{P}<0.05)$.

CR1: sugar beet-wheat-red clover-red clover; CR2: sugar beet-wheat-bean-barley; CR3: corn-wheat-red clover-red clover; CR4: silage corn-wheat-bean-barley.

Table 4. Crop yield references for the irrigated valley of south central Chile.

\begin{tabular}{lccl}
\hline Crop & $\mathrm{Mg} \mathrm{ha}^{-1}$ & Yield & \multicolumn{1}{c}{ References } \\
\hline Sugar beet & $8.7-10.5$ & Grain & Hirzel, 2011 \\
Wheat & $6.9-8.9$ & Grain & $\begin{array}{l}\text { Mellado et al., 2000; } \\
\end{array}$ \\
Red clover & 11.8 & Grain & Hirzel, 2011 \\
Bean & $2.5-3.0$ & Grain & Hirzel et al., 2005 \\
Barley & $5.6-6.5$ & Grain & Inostroza et al., 2007 \\
Corn & $10.5-12.5$ & Dry matter & Hirzel et al., 2011 \\
Silage corn & $21-25$ & Grain & Hirzel et al., 2011 \\
\hline
\end{tabular}

two rotations in which it was included (CR1 and CR2), with average values between 88.9 and $102.8 \mathrm{Mg} \mathrm{ha}^{-1}$, respectively. The productive behavior of the evaluated sugar beet is similar to yields reported by Hirzel (2011), with maximum average yields of $10.5 \mathrm{Mg} \mathrm{ha}^{-1}$ (Table 4). Bean and barley maintained similar yields in all rotations they were included. Bean yielded 3.00 and $3.05 \mathrm{Mg}$ $\mathrm{ha}^{-1}$ and barley 6.5 and $6.8 \mathrm{Mg} \mathrm{ha}^{-1}$ in CR2 and CR4, respectively. The values obtained with bean are promising if compared to those of Hirzel (2011), who reported bean yields for the same area of 2.5 and $3.0 \mathrm{Mg} \mathrm{ha}^{-1}$. Barley yields were on the same order as those obtained in the area in a study by Inostroza et al. (2007), in which yields ranged from 5.6 to $6.5 \mathrm{Mg} \mathrm{ha}^{-1}$ (Table 4). Grain corn in CR3 rotation reached $12.1 \mathrm{Mg} \mathrm{ha}^{-1}$, compared to production levels of 10.5 to $12.5 \mathrm{Mg} \mathrm{ha}^{-1}$ reported for the same location (Hirzel, 2011). Red clover yielded 13.1 and 12.0 $\mathrm{Mg} \mathrm{ha}^{-1}$ in CR1 and CR3, respectively, which were statistically similar and adequate for the region according to Soto et al. (2005), who determined yields of $11.8 \mathrm{Mg}$ $\mathrm{ha}^{-1}$. Silage corn in CR3 yielded $20.3 \mathrm{Mg} \mathrm{ha}^{-1}$, which was slightly lower than 21 and $25 \mathrm{Mg} \mathrm{ha}^{-1}$ reported by Hirzel (2011). Crop sequences in structural studies with similar purposes to this study have resulted in lower wheat yields when grown as a monocrop (2.4 $\mathrm{Mg} \mathrm{ha}^{-1}$ ) (Zentner et al., 2002b).

\section{Economic indicators per crop}

The economic figures of crops express annual averages, independent of the rotation in which they were included. The NGMC, calculated by applying Equations [3] to [5] and RGMC, applying the CF to bean and sugar beet (Figure 1), which generated the highest average real net benefit (US\$5169 and US\$4775 $\mathrm{ha}^{-1}$, respectively). Tzilivakis et al. (2005) reported yields between 50 and $55 \mathrm{Mg} \mathrm{ha}^{-1}$ for sugar beets in a production system under irrigation in the UK, resulting in net incomes of up to US\$994, which is lower than the values obtained in this study, taking into account that results were evaluated in volcanic soils under irrigation with contract farming.

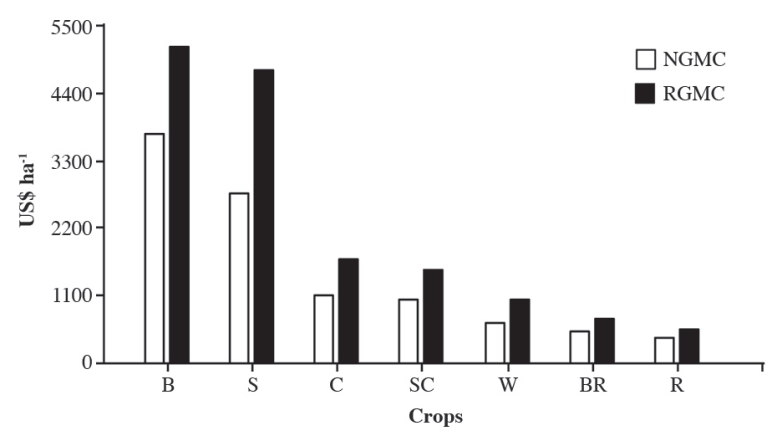

S: sugar beet; W: wheat; R: red clover; B: bean; BR: barley; C: corn; SC: silage corn.

Figure 1. Nominal gross margin per crop (NGMC) and real gross margin per crop (RGMC) after studying four cycles per rotation. In 2010 US dollars. 
Wheat generated a RGMC of US\$1051 ha-1, barley US\$711 ha $\mathrm{h}^{-1}$, and grain corn US\$1691 ha $\mathrm{ha}^{-1}$, which are economically attractive results, although lower than bean and sugar beet. Despite its lower profitability, barley continues to be a feasible and interesting alternative crop for inclusion in rotations.

In forage, the margin of silage corn (US\$1526 ha-1) was notably higher than the real benefit by the red clover pasture (US\$544 ha ${ }^{-1}$ ). Other studies indicate that in some years the cost of transporting forage is an important component of costs and net income (Nielsen et al., 2011). Our study evaluated net income assuming use of forage by the same farm, which is the most common situation represented by the rotations evaluated, therefore, the transportation cost concept was not considered.

Red clover presented a high CV of RGMC (Figure 2), which, added to its low NGMC makes it an unattractive option (Figure 1). The other crops, with the exception of silage corn (0.60), had CV values between 0.29 and 0.35 . Wheat had CV de 0.34 , which represents a strategic economic role of this crop in rotations, given that it shows equilibrium in its profitability and inter-annual dispersion.

\section{Indicators of economic income per rotation}

The economic results of a rotation depend on yield and monetary income of the crops that make up the rotation. The rotations composed only of crops, CR2 and CR4, had a higher annual RNMR (US\$2806 and US\$2020, respectively; Table 5), which increased in both cases because bean, with a higher RGMC (US\$5169; Figure 1) was present in the two rotations. Nemecek et al. (2008)

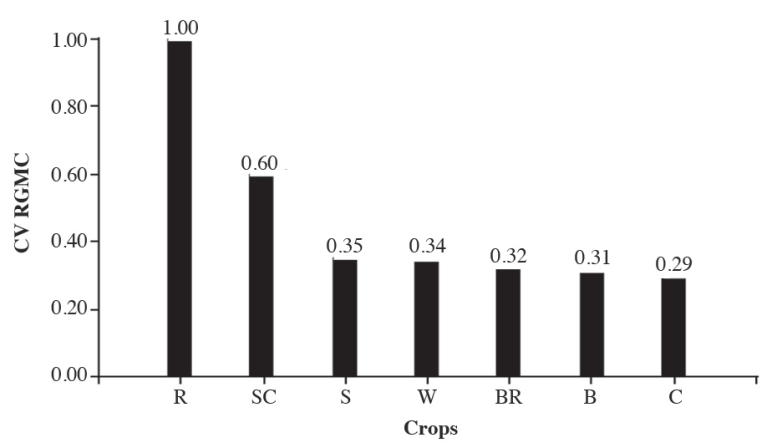

S: sugar beet; W: wheat; R: red clover; B: bean; BR: barley; C: corn; SC: silage corn.

Figure 2. Coefficient of variation $(\mathrm{CV})$ of the real gross margin per crop (RGMC) after studying four cycles per rotation.

Table 5. Real gross margin per rotation (RGMR) and real net margin per rotation (RNMR, with fixed costs), expressed in 2010 US dollars.

\begin{tabular}{llccc}
\hline Rotation system & RGMR & RNMR & SD RNMR \\
\cline { 3 - 5 } & & \multicolumn{3}{c}{ US\$ ha ${ }^{-1}$} \\
CR1 & S-W-R-R & 1565 & 1470 & \pm 505 \\
CR2 & S-W-B-BR & 2900 & 2806 & \pm 514 \\
CR3 & C-W-R-R & 655 & 562 & \pm 261 \\
CR4 & SC-W-B-BR & 2114 & 2020 & \pm 475 \\
\hline
\end{tabular}

S: sugar beet; W: wheat; R: red clover; B: bean; BR: barley; C: corn; SC: silage corn. determined an opposite tendency for grain legumes in an evaluation of rotations with and without legumes in three locations in Europe, finding lower incomes for rotations that included peas and soybean. Nemecek et al. (2008) argued that the lower income is due to lower yields of the legumes than those of oats and wheat.

This type of study must consider that trends in the prices of products, inputs and labor are also an important factor in the economic outcome of rotations. For example, Zentner et al. (2002b) determined that the net average annual benefit of wheat increased with specific changes in its price, while the prices of other rotation crops remained unchanged. This can occur in evaluated rotations in the context of significant changes in price trends of one or more crops. It should be noted that the added role of grain legume crops in rotations is reducing costs in $\mathrm{N}$ fertilizers, which compensates for lower incomes owing to decreased prices or lower yields (Sánchez-Girón et al., 2004; Nemecek et al., 2008). This paper did not examine the pricing behavior, but as indicated in the methodology a nominal annual prices survey was carried out to which supports by the economical indicators.

It was also determined that when the head crop of the rotation is sugar beet (CR2), annual RNMR is $28 \%$ than when the rotation begins with corn (CR4). On the other hand, RNMR of CR1 rotation (S-W-R-R) was $47 \%$ lower than that of CR2 rotation (S-W-B-BR), when $2 \mathrm{yr}$ of pasture were replaced by two crops in rotation.

Finally, RNMR was $61 \%$ higher in rotations that included crops and pastures, like CR1 and CR3, when sugar beet as the lead crop is replaced by silage corn; generated by the sugar beet crop that offsets the lower RGMC of red clover (Figure 1). The CR1 rotation may be more interesting for peasant and family farms because of its short duration and the combination of crops and pasture. These results confirm that not only the sequence, but also the choice of crops in the rotation influences the economic margin (Wilson et al., 2003; Jatoe et al., 2008).

Figure 3 shows RNMR behavior over the 4-yr cycles in length (16 yr), with similar trajectories for rotations CR2 and CR3 and oscillations that resulted in lower economic benefits in the second and fourth cycle. The CR1 rotation had a higher RNMR during the first cycle, while the CR4 rotation had similar behavior over the first two cycles and then increased notably in the last two. The decrease in RNMR in the last cycle could have been due to decreases in real prices. Although rotations can attenuate price volatility, this capacity is variable. Sánchez-Girón et al. (2004) also assessed wheat-vetch, wheat-barley and barley-vetch rotations over $16 \mathrm{yr}$ in Spain and determined different economic returns among the rotations, attributing them to factors beyond control like climate and prices that affect variables like yield, income and costs, which are the main sources of variability or economic uncertainty. 


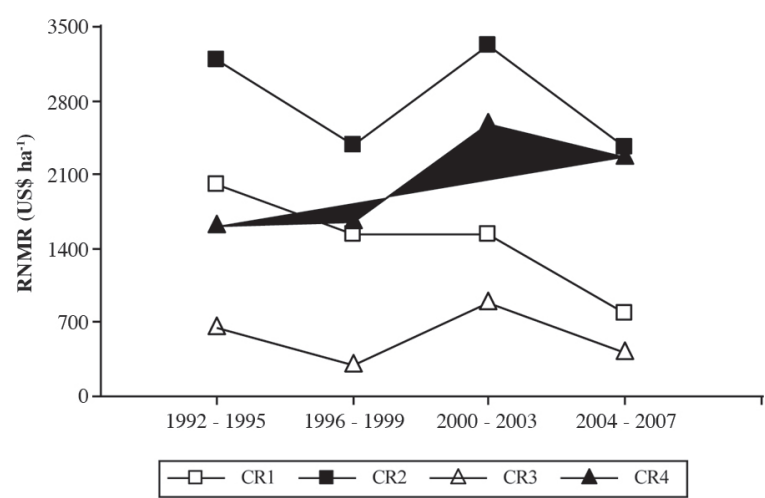

CR1: sugar beet-wheat-red clover-red clover; CR2: sugar beet-wheatbean-barley; CR3: corn-wheat-red clover-red clover; CR4: silage cornwheat-bean-barley.

Figure 3. Evolution of real net margin per rotation (RNMR) after studying four cycles per rotation. Figures are in 2010 US dollars.

\section{Indicators of variability of economic benefits}

Figure 4 and Table 5 present the evolution of the variability of RNMR in the evaluated rotations. The indicators of the economic variability of the rotations under irrigation were evaluated in terms of SD and CV of RNMR, which considers average annual values for each crop rotation for the period of 1992 to 2010 . The SD of the annual RNMR indicates a higher value for the sugar beet-wheat-bean-barley rotation (CR2, Table 5). The CR1 and CR4 rotations present a slightly lower SD than that of CR2 rotation, and the rotation composed of silage cornwheat-red clover (2) (CR3) presented the lowest SD of the net margin ( \pm US\$261). That is, CR3 with a crop-pasture structure has the highest economic stability according to this dispersion indicator of the economic benefit.

In terms of $\mathrm{CV}$, sugar beet-wheat-bean-barley rotation (CR2) presented the lowest CV value (0.18) (Figure 4), while the CR4 corn-wheat-bean-barley rotation also presented a low CV value (0.24). The economic variability of the rotations was on a lower order of magnitude than that reported by Sánchez-Girón et al.

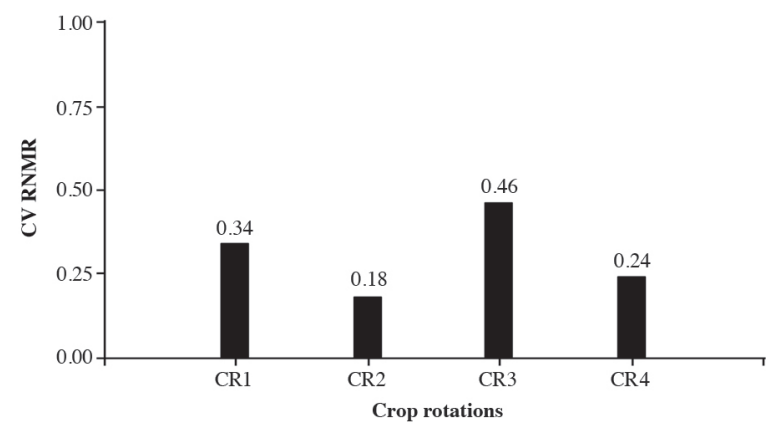

CR1: sugar beet-wheat-red clover-red clover; CR2: sugar beet-wheatbean-barley; CR3: corn-wheat-red clover-red clover; CR4: silage cornwheat-bean-barley.

Figure 4. Coefficient of variation (CV) of the real net margin per rotation (RNMR) after studying four cycles per rotation.
(2004), who obtained a CV between 0.36 and 0.37 for different systems of un-irrigated farming, the latter being a factor that explains the greater variability of economic benefits. Consequently, rotations evaluated in this work that were composed solely of crops had higher stability of the RNMR. Notably, rotations with lower CV values have in common the presence of wheat, barley and bean, which have the lowest individual CV values $(0.34,0.32$, and 0.31 , respectively; Figure 2).

Rotations with crops and pasture (CR1 and CR3) had higher CV values, and CR3 (silage corn-wheat-red clover (2)) had the greatest variability $(\mathrm{CV}=0.46)$, that is, with the greatest uncertainty in terms of expected RNMR. Consequently, rotations with crops and pasture had greater uncertainty or economic volatility owing to the high CV of silage corn (0.60) and red clover (1.00). Sánchez-Girón et al. (2004) determined a CV for their rotations on an order of magnitude similar to those of the CR1 and CR2 rotations, with average values for wheat, barley, and vetch of $0.25,0.30$ and 0.75 , respectively. Bell and Moore (2012) assessed the gross margins of crop and pasture rotations in New South Wales, Australia, which represented different percentages of farmland. They determined a variability of optimal gross margin with a $\mathrm{CV}$ of 0.4 . The studies cited corroborate the reliability of levels of net margin variability determined in the rotations in the present work. Finally, the rotations that included sugar beet (CR1 and CR2) had moderate variability in their economic benefit (RNMR) because sugar beet has an intermediate $\mathrm{CV}$ value $(0.35)$, making such rotations an interesting alternative for a given segment of producers.

\section{CONCLUSIONS}

The economic analysis of rotations based on the construction of real net margin indicators and coefficient of variation $(\mathrm{CV})$ of the real net margin from the experimental agronomic information, collection of pertinent annual nominal price information, and the expression of economic results in comparable monetary units allowed to clearly discriminate crop and grassland rotation performance for a 16-yr database. The longterm experiment consisted of four cycles of 4-yr each. The evaluation produced relevant information over and above the agronomic and productive aspects for farmer decision-making in the selection of crops for rotation.

Crops included in the rotation and their sequence largely determine the long-term economic performance of this rotation. The best real net margin and lowest $\mathrm{CV}$ variability for a rotation is found in crops with low individual CV where the economic performance of wheat, beans, and barley is highlighted; these crops tend to generate medium to high margins and moderate to low CVs. 


\section{LITERATURE CITED}

Anderson, J., J. Dillon, and B. Hardaker. 1988. Selection of a cropping system. Applications in agriculture. II. Agricultural decision analysis. Chapter 8. p. 169-181. University of New England, Biddeford, Maine, USA.

Banco Central de Chile. 2010. Base de datos estadísticos. Índice de precios al consumidor (IPC). IPC general y medidas subyacentes. 1992-2010. Banco Central de Chile, Santiago, Chile. Available at http://si3.bcentral.cl/Siete/secure/cuadros/arboles.aspx (accessed July 2013).

Bell, L.W., and A.D. Moore. 2012. Integrated crop-livestock systems in Australian agriculture: Trends, drivers and implications. Agricultural Systems 111:1-12.

Del Pozo, A., y P. Del Canto. 1999. Áreas agroclimáticas y sistemas productivos en la VII y VIII Regiones. Instituto de Investigaciones Agropecuarias INIA, Centro Regional de Investigación Quilamapu, Chillán, Chile.

Edwards, G. 1992. Matemáticas y estadística en economía. Trabajo Docente N ${ }^{\circ} 52.288$ p. Pontificia Universidad Católica de Chile, Instituto de Economía, Santiago, Chile.

González, J., E. Francisco, y W. Foster. 2002a. Nivel y variabilidad del beneficio económico de rotaciones para la Precordillera Andina de la Región del Bío-Bío. Agricultura Técnica 62:439-449.

González, J., E. Francisco, y W. Foster. 2002b. Selección de portfolios de rotaciones culturales económicamente óptimos para la Precordillera Andina de la VIII Región. Agricultura Técnica 62:583-595.

González, J., y E. Ruz. 1994. La rotación de cultivos. Efecto en la sustentabilidad de los sistemas agrícolas. Revista Investigación y Progreso Agropecuario Quilamapu N ${ }^{\circ}$ 61. p. 6-10. Instituto de Investigaciones Agropecuarias INIA, Centro Regional de Investigación Quilamapu, Chillán, Chile.

Guan, G., S. Tu, J. Yang, J. Zhang, and L. Yang. 2011. A field study on effects of nitrogen fertilization modes on nutrient uptake, crop yield and soil biological properties in rice-wheat rotation system. Agricultural Sciences in China 10:1254-1261.

Hirzel, J. 2011. Fertilización de cultivos en Chile. 2011. Instituto de Investigaciones Agropecuarias INIA, Centro Regional de Investigación Quilamapu, Chillán, Chile.

Hirzel, J., P. Undurraga, and J. González. 2011. Chemical properties of volcanic soil affected by seven-year rotations. Chilean Journal of Agricultural Research 71:304-312.

Informativo Agropecuario Bioleche-INIA Quilamapu. 1999-2007. $\mathrm{N}^{\circ} 1$ a 4, $1999(12), \mathrm{N}^{\circ} 1$ a 4, 2000 (13) $\mathrm{N}^{\circ} 1$ a 4, 2001 (14) $\mathrm{N}^{\circ} 1$ a $4,2002(15) \mathrm{N}^{\mathrm{o}} 1$ a 4, $2003(16) \mathrm{N}^{\circ} 1$ a 4, $2004(17) \mathrm{N}^{\mathrm{o}} 1$ a 4, 2005 (18) $\mathrm{N}^{\circ} 1$ a 4, 2006 (19) $\mathrm{N}^{\circ} 1$ a 4, 2007 (20) $\mathrm{N}^{\circ} 1$ a 4. Bioleche, Los Ángeles, Chile.

Inostroza, L., A. Del Pozo, I. Matus, y P. Hayes. 2007. Tolerancia a la sequía en líneas recombinantes con sustitución de cromosomas (RCSLs) obtenidas de la cruza Hordeum vulgare subsp. spontaneum (Caesarea 26-24) $\times$ Hordeum vulgare subsp. vulgare cv. Harrington. Agricultura Técnica 67:253-261.

Jatoe, J., E. Yiridoe, A., Weersink, and S. Clark. 2008. Economic and environmental impacts of introducing land use policies and rotations on Prince Edwards Island potato farms. Land Use Policy 25:309-319.

Martin, S., and J. Hanks. 2009. Economic analysis of no tillage and minimum tillage cotton-corn rotations in the Mississippi Delta. Soil and Tillage Research 102:135-137.

Mellado, M., R. Madariaga, and D. Granger. 2000. Opala-INIA, a new spring bread wheat cultivar for the South Central area of Chile. Agricultura Técnica 60:415-418.
Nemecek, T., J. von Richthofen, G. Dubois, P. Casta, R. Charles, and H. Pahl. 2008. Environmental impacts of introducing grain legumes into European crop rotations. European Journal of Agronomy 28:380-393.

Nielsen, D.C., M.F. Vigil, and J.G. Benjamin. 2011. Evaluating decision rules for dryland rotation crop selection. Field Crop Research 120:254-261.

ODEPA. 2009a. Servicio de información de la agricultura chilena, estadísticas y precios, series de precios, series combinadas, insumos y productos 1992-2009. Oficina de Estudios y Políticas Agrarias (ODEPA), Ministerio de Agricultura, Santiago, Chile. Available at http://www.odepa.gob.cl/ServletSeriesPreciosScr;js essionid=9134F26ECD4DEE09742BBBE45C7FED8E?modulo $=3 \&$ menu $=$ precios \&item $=$ rubros\&rubro=leguminosas $\quad$ (accessed July 2013).

ODEPA. 2009b. Servicio de información de la agricultura chilena. Estadísticas por macro rubro agrícolas. Estimación de superficie sembrada de cultivos anuales a nivel nacional (2002/20032008/2009). Oficina de Estudios y Políticas Agrarias (ODEPA), Ministerio de Agricultura, Santiago, Chile. http://www.odepa. gob.cl/articulos/MostrarDetalle.action; jsessionid=9134F26ECD 4DEE09742BBBE45C7FED8E?idcla=12\&idn=1736 (accessed July 2013).

Saharawat, Y.S., B. Singh, R.K. Malik, J.K. Ladha, M. Gathala, M.L. Jat, and V. Kumar. 2010. Evaluation of alternative tillage and crop establishment methods in a rice-wheat rotation in North Western IGP. Field Crops Research 116:260-267.

Sánchez-Girón, V., A. Serrano, J.L. Hernanz, and L. Navarrete. 2004. Economic assessment of three long-term tillage systems for rainfed cereal and legume production in semiarid central Spain. Soil and Tillage Research 78:35-44.

SAS Institute. 2002-2003. Software. 9.1.3 Service Pack. SAS Institute, Cary, North Carolina, USA.

SNA. 1991-1996. Boletín Económico y de Mercado. 1991 N 193 a 204; $1992 \mathrm{~N}^{\circ} 205$ a 216 ; $1993 \mathrm{~N}^{\circ} 217$ a 228 ; $1994 \mathrm{~N}^{\circ} 229$ a 240 ; $1995 \mathrm{~N}^{\circ} 241$ a $252 ; 1996 \mathrm{~N}^{\circ} 253$ a 264. Sociedad Nacional de Agricultura (SNA), Santiago, Chile.

Soto, P., E. Jahn, R. Velasco, y S. Arredondo. 2005. Especies leguminosas forrajeras para cortes en suelos arcillosos de mal drenaje. Agricultura Técnica 65:157-164.

Stolpe, N.B. 2006. Descripción de los principales suelos de la VIII Región de Chile. 84 p. Universidad de Concepción, Facultad de Agronomía, Departamento de Suelos y Recursos Naturales, Chillán, Chile.

Tzilivakis, J., K. Jaggard, K.A. Lewis, M. May, and D.J. Warner. 2005. Environmental impact and economic assessment for UK sugar beet production systems. Agriculture, Ecosystems and Environment 107:341-358.

Undurraga, P., E. Zagal, G. Sepúlveda, and N. Valderrama. 2009. Dissolved organic carbon and nitrogen in Andisol for six crop rotation with different soil management intensity. Chilean Journal of Agricultural Research 69:445-454.

Wilson, P., J. Gibbons, and S. Ramsden. 2003. The impact of cereal prices and policy on crop rotations and supply response. Journal of Agricultural Economics 54:313-323.

Zentner, R.P., G.P. Lafond, D.A. Derksen, and C.A. Campbell. 2002b Tillage method and crop diversification: effect on economic returns and riskiness of cropping systems in a Thin Black Chernozem of the Canadian Prairies. Soil and Tillage Research 67:9-21.

Zentner, R., D. Wall, C. Nagy, E. Smith, D. Young, and P. Miller. 2002a. Economics of crop diversification and soil tillage opportunities in the Canadian prairies. Agronomy Journal 94:216230 . 